\title{
DYNAMICS OF SEXUAL REGENERATION IN THREE NATIVE OAK SPECIES (QUERCUS BRANTII LINDL., Q. INFECTORIA OLIV., AND Q. LIBANI OLIV.) OF ZAGROS FORESTS, IRAN
}

\author{
PANAHI, P. ${ }^{1 *}$ - JALILI, A. ${ }^{1}$ - JAMZAD, Z. ${ }^{1}$ - POURHASHEMI, M. ${ }^{2}-$ HASANINEJAD, M. ${ }^{1}$ \\ ${ }^{I}$ National Botanical Garden of Iran, Research Institute of Forests and Rangelands, Agricultural \\ Research, Education and Extension Organization (AREEO) \\ P. O. Box: 13185-116, National Botanical Garden of Iran, Research Institute of Forests and \\ Rangelands, Tehran, Iran \\ ${ }^{2}$ Forest Research Division, Research Institute of Forests and Rangelands, Agricultural \\ Research, Education and Extension Organization (AREEO) \\ P. O. Box: 13185-116, Forest Research Division, Research Institute of Forests and Rangelands, \\ Tehran, Iran \\ *Corresponding author \\ e-mail: panahi@rifr-ac.ir; phone: +98-21-44787282-5; fax: +98-21-44787223
}

(Received $30^{\text {th }}$ Apr 2017; accepted $1^{\text {st }}$ Aug 2017)

\begin{abstract}
Zagros forests of Iran have been historically degraded by anthropogenic and other biotic and abiotic factors. As a result of multiple factors, seedlings and saplings establishment of Zagros oaks rarely happens and their dynamic is still unknown. Because of many difficulties to study the dynamics of oak sexual regeneration in Zagros forests, we focused on all of three Zagros oaks (Quercus brantii Lindl., $Q$. infectoria Oliv., and Q. libani Oliv.) planted in National Botanical Garden of Iran. We conducted 8 fullcensus inventories from the early September 2013 to the late September 2016 to monitor the trend of regeneration loss. The results showed that the $77.7 \%, 87 \%$, and $89.8 \%$ of the total produced acorns in $Q$. brantii, $Q$. infectoria and $Q$. libani are demolished prior to germination and establishment in forest floor, respectively. Besides, only $4.4 \%, 3.2 \%$, and $2.1 \%$ of produced acorns have the chance to become threeyear saplings in the studied species. The results confirm the important role of wildlife in consumption of acorns and the variety in survival trends of saplings among the studied oak species. Study of sapling establishment in longer period and to conduct similar researches on other native oak species of Iran could be suggested for future studies.
\end{abstract}

Keywords: acorn, monitoring, sapling, seedling establishment, survival

\section{Introduction}

Historically, one of the most important challenges and responsibilities of the forest managers has been to promote regeneration in forests (Nyland et al., 2016). Acorn production plays a fundamental role in the organization, dynamics and sustainability of oak forest ecosystems (Rose et al., 2012). The abundance of acorns directly affects the regeneration of oak and the abundance of acorn-consuming animal species, and indirectly affects the predators and parasites of acorn consumers (Dey, 1995; McShea and Healy, 2002; Greenberg and Warburton, 2007).

Acorn production is characterized by extreme variation among years (Sork et al., 1993; Koenig et al., 1994a; Greenberg, 2000; Steen et al., 2009; Koenig and Knops, 2014) and individual trees (Auchmoody et al., 1993; Koenig and Knops, 1998; GeaIzquierdo et al., 2006). The size of acorn crops affects many components of the ecosystem, and both annual and individual variation in acorn production influence the regeneration and management of oak forests. Acorn production is influenced by 
weather, insects, wildlife, tree age and size, tree crown position, and the tree`s inherent capacity to produce acorns (Dey, 1995).

Many organisms consume acorns, including insects, millipedes, fungi, birds and mammals. Consumption by one or more biotic agents is often so complete that in any given year few acorns remain to germinate and develop to seedlings. Although this consumption contributes to oak regeneration failures, acorns are valuable sources of food for many birds and mammals because of their high caloric content, nourishment and availability during seasons when other food is often scarce (Johnson et al., 2009). The term dispersal is used to refer to the transport of acorns from their place of origin (i.e. tree crowns or the forest floor) to other locations. Birds and mammals are the most important dispersers of acorns, which that nearly consume all the acorns they disperse, thus clearly causing some degree of loss to potential seedling establishment. Dispersers may also consume significant quantities of acorns at their place of origin. If proportionately few acorns are consumed by a disperser, dispersal may be advantageous to the oak if acorns are dispersed in significant number to habitats that are favorable for seedling establishment (Johnson et al., 2009).

Rodents, together with other animals, often consume most of the acorn crop following their fall. Thus, establishment of oak seedlings occur primarily in years when the amount of sound acorns exceeds the demand for acorns by insects and wildlife (Christisen and Kearby, 1984). Production of sound acorns exceeds this level only during years with good to bumper acorn crops (Beck, 1977).

Factors influencing early survival and growth of seedling beneath a stand may be very different from those determining growth of saplings. Initial survival and early growth of oak seedlings are primarily dependent on stored food reserves in the acorns. Light is a dominant environmental factor limiting seedling establishment and soil moisture may also limit establishment. Oak seedlings begin spring growth, when both light and soil moisture conditions are favorable (Johnson et al., 2009). Oaks are generally regarded as drought tolerant, whereas oak seedlings are relatively shadeintolerant. Under closed and dense canopies, oak seedlings cannot survive long (Crunkilton et al., 1992).

Quercus sp. is the most frequent genus of Fagaceae in forests of Iran (Sabeti, 2016). Oaks are the most prevalent forest types in Iran and dominate most of the Zagros landscape. Zagros forests are the most important and sensitive forest ecosystems of Iran with an area of about 6 million ha (Pourhashemi et al., 2004; Sagheb Talebi et al., 2014). Various factors such as traditional overutilization from timber and non-timber products, forest land conversion to agricultural lands, overgrazing, and road and dam constructions, have contributed to the degradation of these forests. Besides, many individual oaks are affected by decline phenomenon during the last decade. In this situation, oaks produce acorns, but seedlings and saplings are rarely established on the forest floor (Sagheb Talebi et al., 2014). All in all, the study of sexual regeneration dynamic of Zagros oaks is impossible because of degradation factors.

Although dynamics of acorn production have been studied in various researches worldwide (e.g. Koenig et al., 1994b; Greenberg, 2000; Abrahamson and Layne, 2003; Perez-Izquierdo and Pulido, 2013), a few researchers (e.g. Panahi et al., 2009; Pourhashemi et al., 2013, 2015) published studies on native oaks of Zagros region in Iran. Furthermore, there is no research on sexual regeneration dynamics of Zagros native oaks. 
During the past three decades, native oak species of Zagros forests are planted in National Botanical Garden of Iran (NBGI), for ex situ conservation. With an area of about 150 ha, the NBGI is the most important and the largest botanical garden in Iran. Today, oak species are one of the most important elements of the NBGI which are distributed throughout the garden, mainly within the Zagros collection. The mature oak individuals normally produce acorns and regenerate sexually. This garden can be considered as the unique place of Iran in which there is potential form of oak sexual regeneration. Our study of sexual regeneration dynamics has been partly enabled due to the fact that the oak collection of NBGI is protected from destruction of acorns by livestock or harvesting by humans.

\section{Material and methods}

\section{Study area}

The study was conducted at NBGI $\left(35^{\circ} 41^{\prime} \mathrm{N}, 51^{\circ} 19^{\prime} \mathrm{E}\right)$ from 2013 to 2016 . The garden was founded in 1968 in the vicinity of Tehran at an altitude of about $1320 \mathrm{~m}$. The terrain is flat and slopes gently to the south. The climate is dry with an average annual precipitation of about $257 \mathrm{~mm}$ falling between November and May. Temperature reaches as much as $42-43^{\circ} \mathrm{C}$ during July and August. During winter the temperature may fall to $-10^{\circ} \mathrm{C}$ or lower. The garden consists of different native and exotic collections such as Alborz, Himalayan and Rock garden (Fig. la). The Zagros collection is one of the most important forest collections of the garden that covers an area of ca. 3 ha. Most of the oak trees are found in these collections (Fig. 1b).

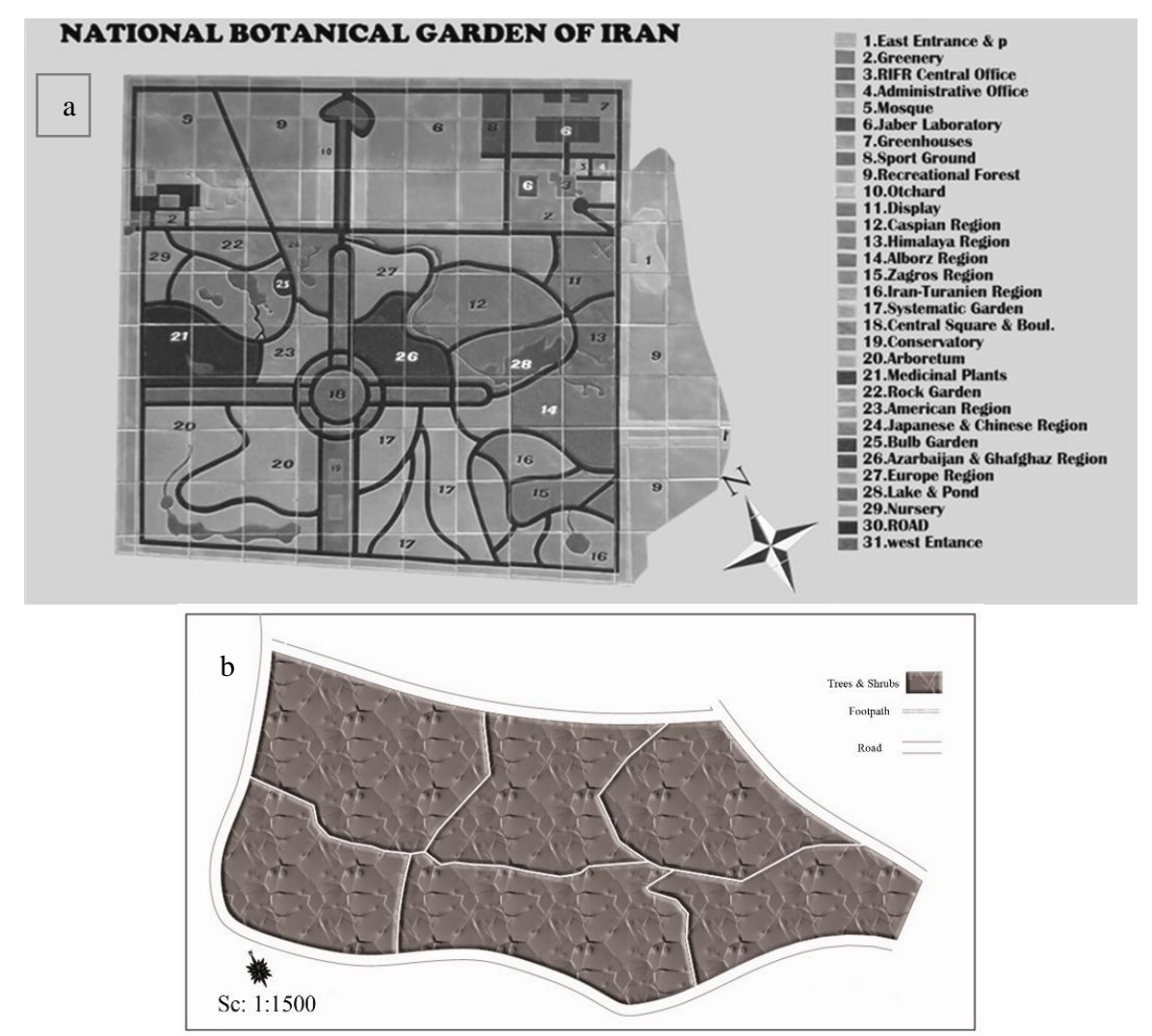

Figure 1. Map of the NBGI (a) and Zagros collection (b) 


\section{The studied species}

All of three main oak species of Zagros forests planted in NBGI were considered for this study, including Lebanon oak ( $Q$. libani Oliv.), Aleppo oak ( $Q$. infectoria Oliv.) and Brant's oak ( $Q$. brantii Lindl.). The studied oaks naturally grow in Zagros forests. Quercus libani is only widespread in northern Zagros (West Azerbaijan and Kurdistan provinces), while $Q$. infectoria is widely distributed in West Azerbaijan, Kurdistan, Kermanshah and Lorestan provinces. Compared to Lebanon oak, Brant`s oak is usually found on northern slopes as well but at lower elevations. Quercus brantii is more resilient and tolerant than the other two oak species and its geographic distribution is not limited by elevation or aspect, thus it is found at various aspects and elevations. It occurs throughout the Zagros forests, mainly in the southern and central areas (Sagheb Talebi et al., 2014).

\section{Sampling procedure}

After initial garden survey, 5 sample trees were selected for each oak species in flat areas. The selected trees were larger than $15 \mathrm{~cm}$ in diameter at breast height (DBH), and dominant in crown position. Furthermore, the crown of adjacent trees had no contact. Two full callipering were done in the first year of the research. In the first callipering, the number of acorns per tree was determined by crown count method (Gysel, 1956) in early September, just prior to acorn fall. The counted acorns considered as potential of the sample oak trees. To standardize comparisons among different sized trees and simplify the usage by forest management, the numbers of acorns per tree were converted to the number per $\mathrm{m}^{2}$ crown area per tree (acorn density) by dividing the total acorn production of each tree by its crown area (Christisen and Kearby, 1984; Rose et al., 2012). The second full callipering was conducted in late December after full acorn fall and included counting the numbers of acorns beneath the sample tree crowns. The difference of acorn number between the two inventories indicates the portion of acorns which have been consumed by animals directly from the trees.

In the second year of the research, two other full callipering (termed as third and fourth inventories) were carried out in the first (early May) and the end (late September) of the growing season, in which all of the established seedlings under the sample tree crowns were counted. The differences of acorns and seedlings number between second and third inventories indicate portion of the acorns that could pass the winter and transform to the seedlings in the next spring. The differences of seedlings between the beginning and the end of growing season show the portion of seedlings that could pass the summer. The same inventory procedure was done in the third and fourth years of the study to determine the losses of 2-year and three-year saplings.

\section{Statistical analysis}

The rate of survival was initially calculated for each species. For comparing the losses of different inventory stages, the numbers of acorns, seedlings and saplings were converted to percent. Normal distribution of variables was assessed by test of ShapiroWilk test $(\mathrm{p}<0.01)$ and the homogeneity of variances was assessed by Levene test. The acorn density was natural-log transformed for ANOVA to reduce the correlation between the mean and variance (Sakal and Rohlf, 2012). The differences of acorn, seedling and sapling abundances in each species were tested by non-parametric 
Kruskal- Wallis test. In addition, pairwise comparison was done by Mann- Whitney U test. Statistical significance was reported at the $\mathrm{p}<0.05$ level unless otherwise stated.

\section{Results}

Detailed quantitative characteristics of sample trees are summarized in Table 1. Based on one-way ANOVA analysis, there was no significance difference among the studied species regarding to acorn density $(\mathrm{df}=2, \mathrm{p}<0.061, \mathrm{~F}=3.568)$. The numbers of acorns produced by sample trees are shown in Fig. 2.

Table 1. Quantitative characteristics of sample trees

\begin{tabular}{lcccccc}
\hline \multirow{2}{*}{\multicolumn{1}{c}{ Variable }} & \multicolumn{2}{c}{ Q. brantii } & \multicolumn{2}{c}{ Q. infectoria } & \multicolumn{2}{c}{ Q. libani } \\
\cline { 2 - 7 } & Mean & Range & Mean & Range & Mean & Range \\
\hline Diameter at breast height $(\mathrm{cm})$ & 27.6 & $21-34$ & 27 & $22-34$ & 23.6 & $19-27$ \\
Crown area $\left(\mathrm{m}^{2}\right)$ & 33.9 & $26.9-41.3$ & 27.5 & $20.4-36.3$ & 23.3 & $15.5-30.7$ \\
Number of acorns per tree & 758.4 & $228-2020$ & 1597.4 & $700-3032$ & 801.8 & $204-1453$ \\
Number of acorns per $\mathrm{m}^{2}$ crown & 21 & $7.6-51$ & 63.4 & $30.6-148.5$ & 34 & $9.1-65.9$ \\
\hline
\end{tabular}

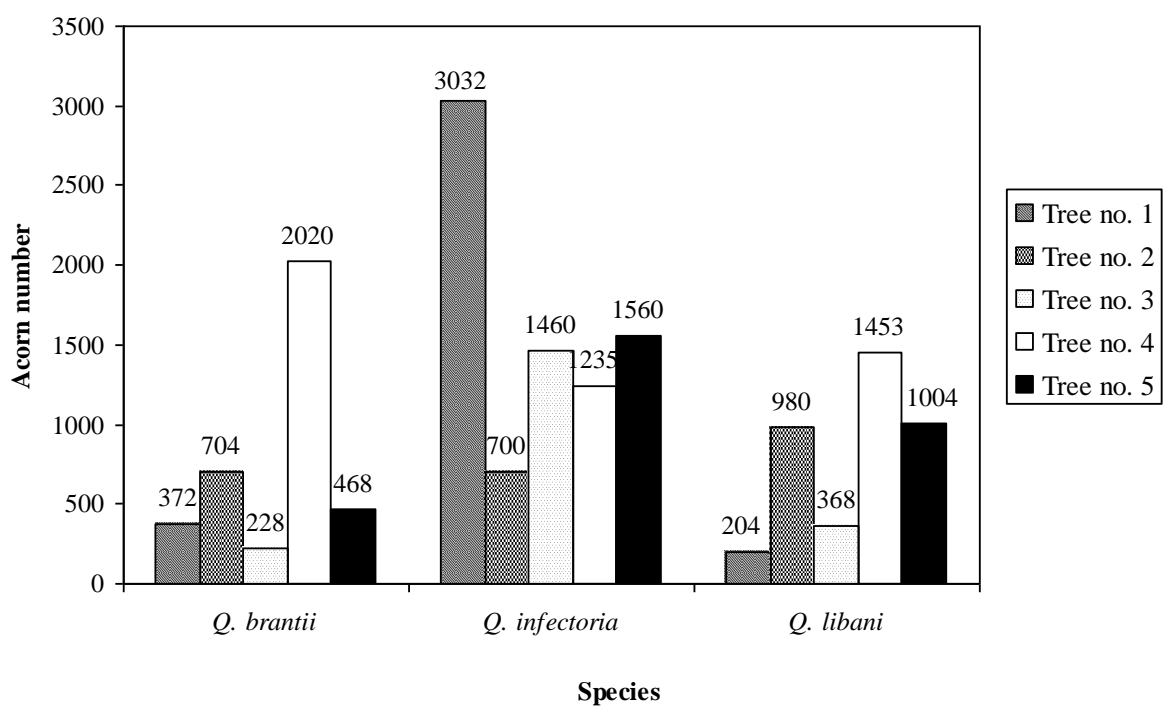

Figure 2. Number of acorns of the studied oak species

Losses of sexual regeneration from acorn to three-year saplings for each species are shown in Fig. 3. Totally, three main trends were observed as follows:

- Some individual trees produced large number of acorns (more than 1500) and the losses were moderately sever or sever. The losses of these individual trees were more than 90 percent (e.g. tree no. 4 in all three studied oak species and tree no. 1 in Q. infectoria).

- Some individuals produced moderate number of acorns (between 500 to 1500) and the losses were moderate, too (e.g. trees no. 2 in both of $Q$. brantii and $Q$. infectoria and trees no. 2 and 5 in $Q$. libani).

- Some individuals produced low number of acorns (less than 500) and the losses were moderate (e.g. trees no. 1 and 3 in both of $Q$. brantii and Q. libani). 
There were some considerable cases among the sample trees. For instance, the acorn production potential of tree no. 1 in $Q$. infectoria was remarkably more than the others due to its 3032 produced acorns. Another exceptional case was observed in tree no. 5 in Q. libani. While it produced 1004 acorns, no established seedlings were observed beneath its crown.

Survival percentage showed no significance difference among studied species $\left(\chi^{2}=\right.$ $0.384 ; \mathrm{p}=0.825$ ) and among same inventory stages (Fig. 4). In other words, the three studied oaks had similar rates of loss in same inventory stages, but the differences among inventory stages in each species was significant $\left(Q\right.$. brantii: $\mathrm{df}=6, \chi^{2}=19.49, \mathrm{p}$ $=0.002 ; Q$. infectoria: $\mathrm{df}=6, \chi^{2}=21.216, \mathrm{p}=0.001 ; Q$. libani: $\mathrm{df}=6, \chi^{2}=21.997, \mathrm{p}=$ $0.001)$.
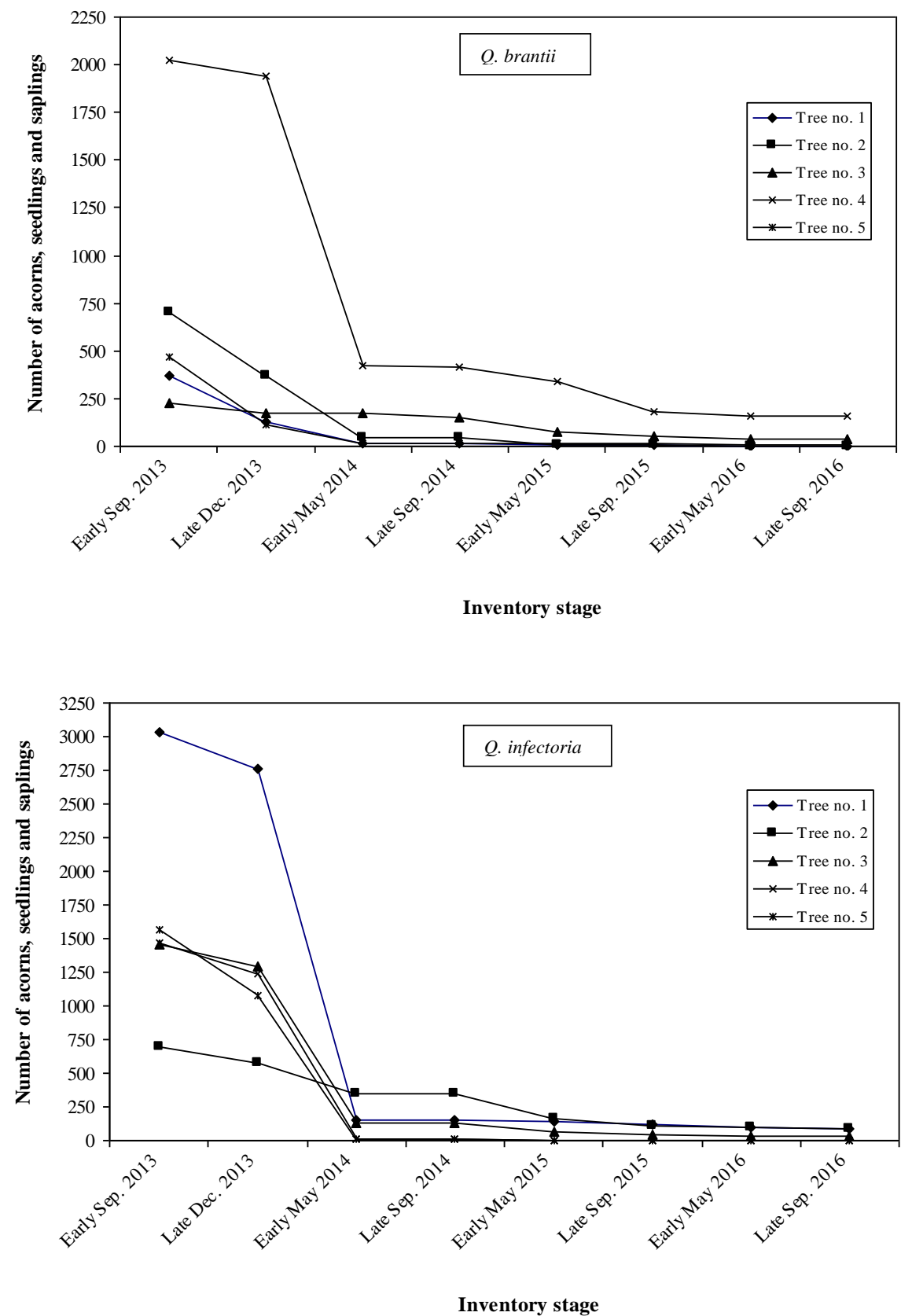


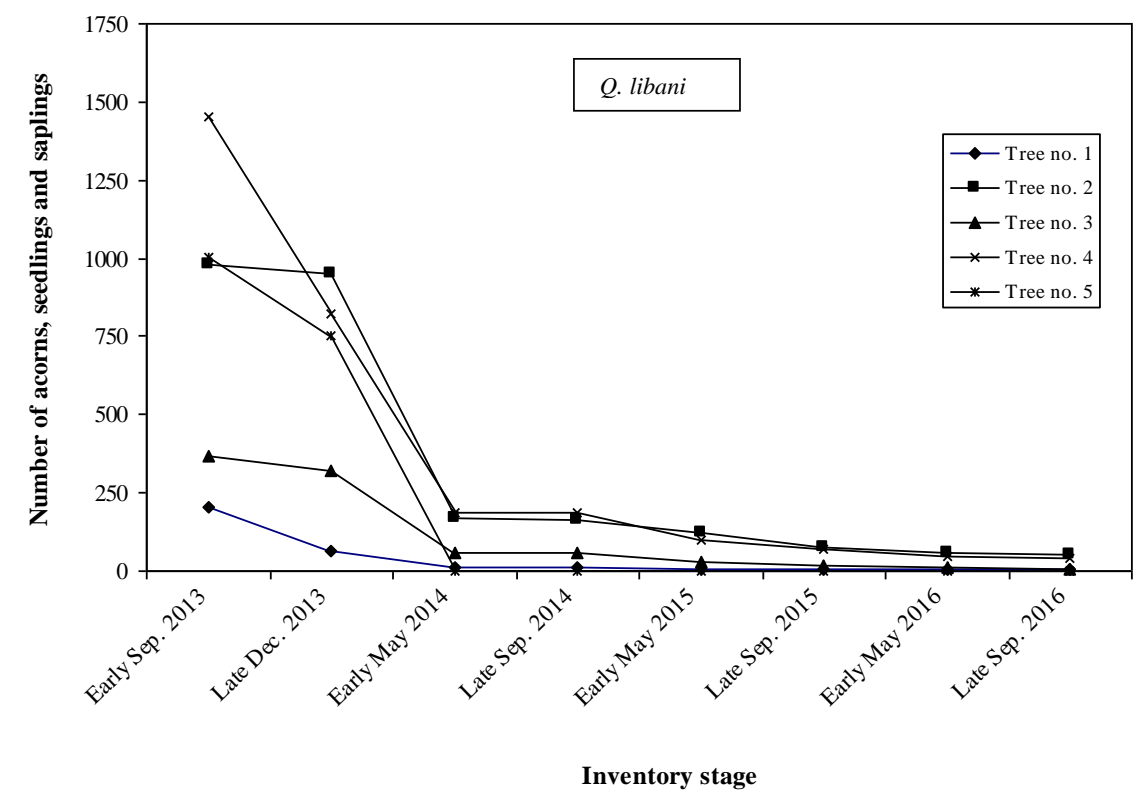

Figure 3. The proportion of the studied oak acorns that produce seedlings and saplings

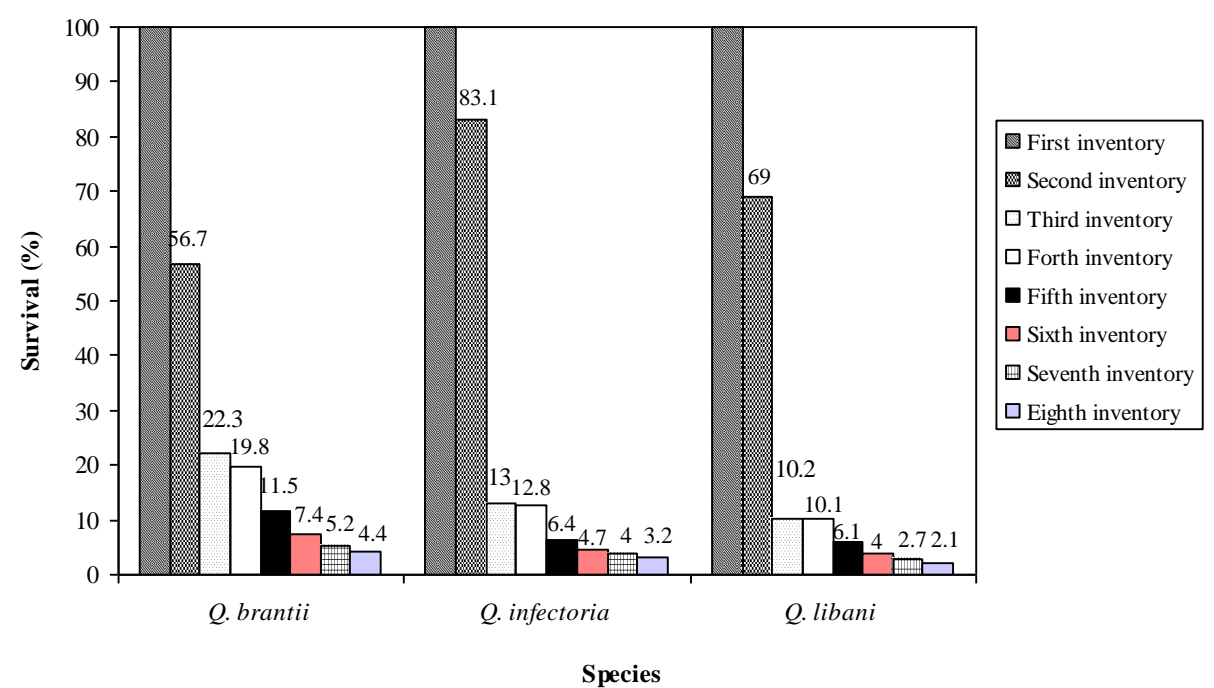

Figure 4. The survival (percent) from acorn to three-year sapling in the studied species (results of the inventory stages comparison: First inventory: $d f=2, \chi^{2}=0, p=1$; second inventory: $d f$ $=2, \chi^{2}=2, p=0.368$; third inventory: $d f=2, \chi^{2}=0.62, p=0.733$; forth inventory: $d f=2, \chi^{2}$ $=0.62, p=0.733$; fifth inventory: $d f=2, \chi^{2}=0.26, p=0.787$; sixth inventory: $d f=2, \chi^{2}=$ $0.32, p=0.852$; seventh inventory: $d f=2, \chi^{2}=0.28, p=0.82$; eighth inventory: $d f=2, \chi^{2}=$ $0.22, p=0.832)$

Based on the pairwise comparison of the losses in inventory stages, significant difference was observed after the second inventory stage in $Q$. brantii. However, the same condition did not hold true after the third inventory stage in $Q$. infectoria and $Q$. libani (Figs. 5, 6). 


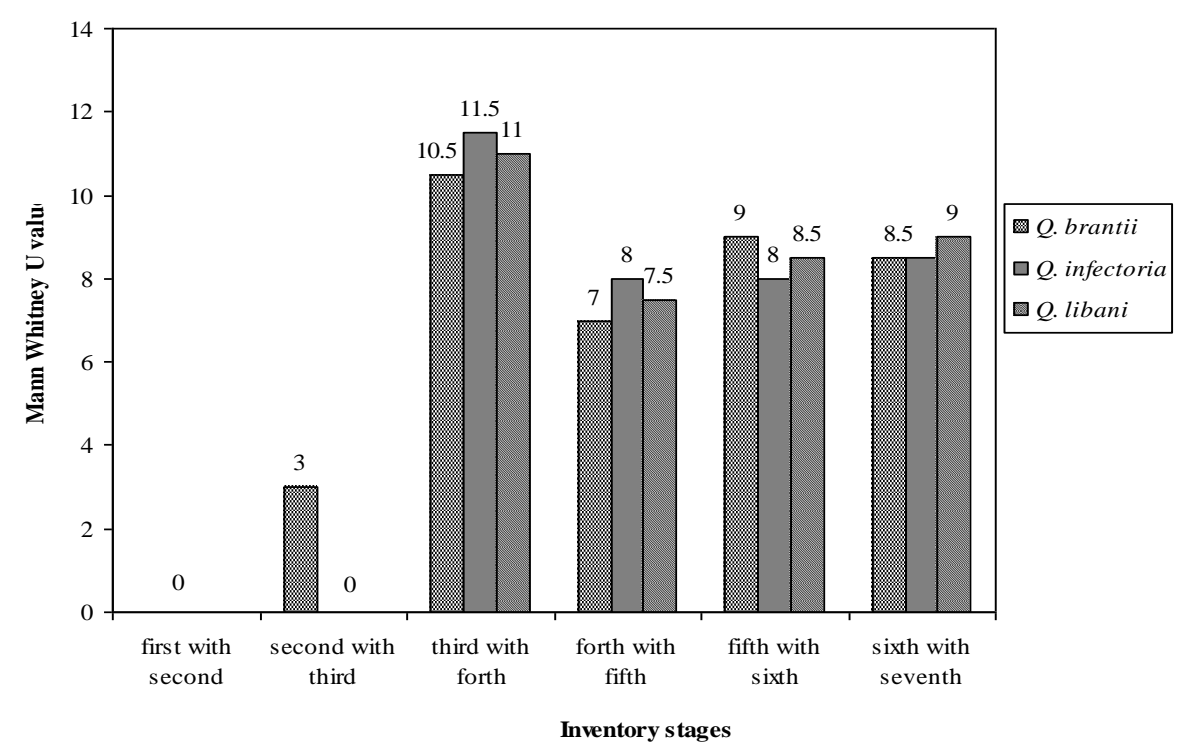

Figure 5. Mann-Whitney $U$ values of pairwise comparison of the inventory stages in the studied species (The losses percent between the first and second stages of inventory was considered as the first inventory stage)

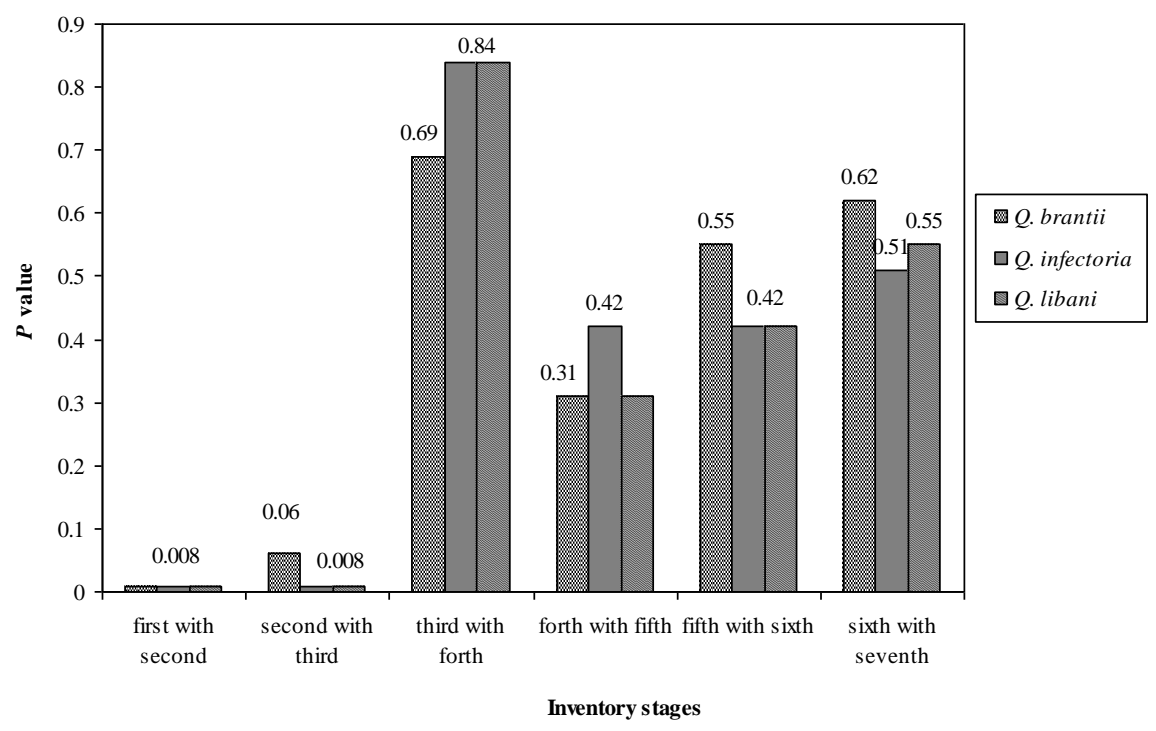

Figure 6. P values of pairwise comparison of the inventory stages in the studied species (The losses percent between the first and second stages of inventory was considered as the first inventory stage)

\section{Discussion}

Our results confirm that acorn production significantly vary from tree-to-tree for each oak species. Some researchers have emphasized this variation in oaks (e.g. Greenberg, 2000; Rose et al., 2012; Koenig and Knops, 2014). All our sample trees were similar regarding to the $\mathrm{DBH}$, crown area, crown position, and environmental factors. Therefore, the differences of acorn production among studied species can be attributed to inherent characteristics of the trees. Although the tree no. 4 in Q. infectoria showed a high rate of acorn production, it was difficult to consider it as an inherently 
good producer without long-term monitoring of acorn production. On the other hand, the two-year maturation of acorns in $Q$. libani and Q. brantii (Djavanchir Khoie, 1967) might have been affected by the climatic factors during the year before the first year of the study.

The average number of acorns in $Q$. brantii, Q. infectoria and $Q$. libani were 21, 63.4 and 34, respectively. In a same research in the NBGI, mean values of acorn production were 46.5, 52.4, and 31 in 2006 (Panahi et al., 2009). The differences of acorn production between 2006 and 2013 confirm the year-to-year variability of acorn production in the same species, which had been the subject of a number of studies (e.g. Steen et al., 2009; Koenig and Knops, 2014). One may also note that the number of sample trees and their quantitative variables could affect the average number of produced acorn.

Losses of acorn production due to insects, birds and mammals can be very high. Although the role of insects is very important in destroying the acorns, no damages were observed in the studied oak species in the NBGI, which is obviously due to the conservation status of the garden. About $10-25 \%$ of acorns are taken directly from the trees by animals such as birds and squirrels (Beck, 1977; Myers, 1978). Our results showed the remarkable rate of consumption of acorns by rodents especially squirrels, and birds especially crows, woodpeckers, and rabbits. The maximum consumption of acorns directly from the trees occurred in $Q$. brantii $(43.3 \%$ of the total produced acorns), while the values for $Q$. infectoria and $Q$. libani were $17.1 \%$ and $31 \%$, respectively. Totally, the portion of acorns taken directly from the trees was more than the average global range of $10-25 \%$. Of course the bigger size of acorns in $Q$. brantii and $Q$. libani in comparison with $Q$. infectoria (Djavanchir Khoie, 1967) can be further reason for higher consumption rate. It is not clear whether seedling establishment is positively related to acorn size (Sork, 1993; Díaz et al., 2003). The role of acorn size is controversial: bigger acorns are preferably consumed by predators (Gómez, 2004), which might hamper regeneration. On the other hand, seedlings from bigger acorns are associated with an average higher number of leaves and leaf area (Díaz et al., 2003), which might be an advantage for young seedlings.

As a general rule of overwintering, acorns require protection from desiccation, low temperatures and predation by insects, rodents and other animals (Johnson et al., 2009). The same applied for the losses of acorns from early September 2013 to late December 2013, as the proportion of acorns consumed by wildlife from ground surface during winter was high $(34.4 \%, 70.1 \%$, and $58.8 \%$ of the total produced acorns in Q. brantii, $Q$. infectoria and $Q$. libani, respectively; Fig. 4). Obviously a minor portion of this loss could be related to the low viability of acorns in the studied species. High rate of acorn consumption by wildlife in the garden, both directly from the crown and from forest floor, indicate their important role in sexual regeneration chain of oaks. Totally, $77.7 \%$, $87 \%$, and $89.8 \%$ of total produced acorns were destroyed prior to the spring of 2014 in $Q$. brantii, $Q$. infectoria and $Q$. libani, respectively (Fig. 4). In $Q$. brantii, significant difference amongst losses was observed in the interval between the first and second inventory stages (Fig. 6), but the situation was a little different in $Q$. infectoria and $Q$. libani. Furthermore, in these species the losses were significantly different during winter after acorn fall. The loss trends for all of the studied species decreased after the third inventory stage (Fig. 4).

Based on our garden surveys, the canopy was closed with minor gaps, though the crowns of the studied oak trees had no overlap or contact. On the other hand, soil 
moisture in the garden cannot be considered as a limiting factor because of the irrigation of the garden during dry seasons. It seems that the role of light is very important in germination and early growth of acorns in the garden.

Our results showed that the mortality rate of saplings in $Q$. libani was higher $(81.7 \%)$ than the others $(74.5 \%$ in $Q$. brantii and $74.9 \%$ in $Q$. infectoria). Excessive shade and competition are the most important reasons for the slow growth and mortality of saplings. The ability to persist under shade appears to vary among oak species (Lormier, 1992), which was also confirmed by our results.

\section{Conclusion}

This study mainly confirms the role of botanical gardens as appropriate sites for studying subjects that are impossible to be studied elsewhere. Besides, absence of degradation factors parallel with conservation of oak species provides an ideal condition to study the potential of trees. As previously mentioned, due to multiple reasons it is not possible to study the sexual regeneration dynamics of oak species in natural Zagros forests of Iran, including traditional utilization of acorns by forest residents, livestock grazing, and rain-fed agriculture underneath the trees. Finally, study on annual variation of acorn production, the effect of different factors on acorn production, and advantages and disadvantages of rodents and birds (as the most important acorn consumers) are the main motivations for further research.

Acknowledgements. This research is supported by the research program 2-09-09-92139 from the Research Institute of Forests and Rangelands, Iran. Thanks are due to Dr. Latifi, Dr. Sadeqzade, Mr. Vahdatian, and Mr. Azarsa for their collaboration.

\section{REFERENCES}

[1] Abrahamson, W. G., Layne, J. N. (2003): Long- term patterns of acorn production for five oak species in xeric Florida uplands. - Ecology 84(9): 2476-2492.

[2] Auchmoody, L. R., Smith, H. C., Walters, R. S. (1993): Acorn production in northern red oak stands in northwestern Pennsylvania. - Research Paper NE-680, PA: US. Department of Agriculture, Forest Service, Northeastern Forest Experiment Station, Radnor.

[3] Beck, D. E. (1977): Twelve-year acorn yield in southern Appalachian oaks. - Research Note SE-244, NC: U.S. Department of Agriculture, Forest Service, Southeastern Forest Experiment Station, Asheville.

[4] Christisen, D. M., Kearby, W. H. (1984): Mast measurement and production in Missouri (with special references to acorns). - Missouri Department of Conservation, Terrestrial Series 13, Missouri.

[5] Crunkilton, D. D., Pallardy, S. G., Garrett, H. E. (1992): Water relations and gas exchange of northern red oak seedlings planted in a central Missouri clearcut and shelterwood. - Forest Ecology and Management 53: 117-129.

[6] Dey, D. C. (1995): Acorn production in red oak. - Forest Research Information Paper No: 127, Ontario Forest Research Institute, Ontario.

[7] Díaz, M., Mǿller, A. P., Pulido, F. J. (2003): Fruit abortion, developmental selection and developmental stability in Quercus ilex. - Oecologia 135: 378-385.

[8] Djavanchir Khoie, K. (1967): Les chênes de L'Iran. - Ph. D. Thesis, Faculté des Sciences, Université de Montpellier, Montpellier. 
[9] Gea-Izquierdo, G., Cañellas, I., Montero, G. (2006): Acorn production in Spanish holm oak woodlands. - Investigación agraria. Sistemas y Recursos Forestales 15(3): 339-354.

[10] Gómez, J. M. (2004): Bigger is not always better: conflicting selective pressures on seed size in Quercus ilex. - Evolution 58: 71-80.

[11] Greenberg, C. H. (2000): Individual variation in acorn production by five species of southern Appalachian oaks. - Forest Ecology and Management 132: 199-210.

[12] Greenberg, C. H., Warburton, G. S. (2007): A Rapid Hard-Mast Index From Acorn Presence-Absence Tallies. - Wildlife Management 71(5): 1654-1661.

[13] Gysel, L. W. (1956): Measurement of acorn crops. - Forest Science 2(1): 305-313.

[14] Johnson, P. S. (1994): How to manage oak forests for acorn production. - Technical Brief TB-NC-1, US. Department of Agriculture, Forest Service, North Central Forest Experiment Station.

[15] Johnson, P. S., Shifley, S. R., Rogers, R. (2009): The Ecology and Silviculture of Oaks. CABI Publishing, New York.

[16] Koenig, W. D., Knops, J. M. H. (1998): Testing for spatial autocorrelation in ecological studies. - Ecography 21: 423-429.

[17] Koenig, W. D., Knops, J. M. H. (2014) Environmental correlates of acorn production by four species of Minnesota oaks. - Population Ecology 56(1): 63-71.

[18] Koenig, W. D., Knops, J. M. H., Carmen, W. J., Stanback, M. T., Mumme, R. L. (1994a): Estimating acorn crops using visual surveys. - Canadian Journal of Forest Research 24: 2105-2112.

[19] Koenig, W. D., Mumme, R. L., Carmen, W. J., Stanback, M. T. (1994b): Acorn production by oaks in central coastal California: variation within and among years. Ecology 75(1): 99-109.

[20] Lormier, C. G. (1993): Causes of the oak regeneration problem. - In: Loftis, D., McGee, C. E. (eds.) Symposium Proceedings on Oak Regeneration: Serious Problems, Practical Recommendations, Knoxville, Tennessee, pp. 14-39.

[21] McShea, W. J., Healy, W. M. (2002): Oak Forest Ecosystems: Ecology and Management for Wildlife. - Johns Hopkins University Press, Baltimore.

[22] Myers, S. A. (1978): Insect impact on acorn production in Missouri upland forests. - Ph. D. dissertation, University of Missouri, Columbia.

[23] Nyland, R. D., Kenefic, L. S., Bohn, K. K., Stout, S. L. (2016): Silviculture, Concepts and Applications. - Waveland Press, Inc., Illinois.

[24] Panahi, P., Jamzad, Z., Pourhashemi, M. (2009): Acorn production of Zagros forests oaks and their qualitative characteristics in Zagros section of National Botanical Garden of Iran. - Journal of Forest and Wood Products (Iranian Journal of Natural Resources) 62(1): 45-57. (In Persian with English summary)

[25] Perez-Izquierdo, L., Pulido, F. (2013): Spatiotemporal variation in acorn production and damage in a Spanish holm oak (Quercus ilex) dehesa. - Forest Systems 22(1): 106-113.

[26] Pourhashemi, M., Marvi Mohajer, M. R., Zobeiri, M., Zahedi Amiri, Gh. Panahi, P. (2004): Identification of forest vegetation units in support of government management objectives in Zagros forests, Iran. - Scandinavian Journal of Forest Research 19(Suppl. 4): 72-77.

[27] Pourhashemi, M., Panahi, P., Zandebasiri, M. (2013): Application of visual surveys to estimate acorn production of Brant`s oak (Quercus brantii Lindl.) in northern Zagros Forests of Iran. - Caspian Journal of Environmental Sciences 11(2): 85-95.

[28] Pourhashemi, M., Pourreza, M., Khodakarami, Y., Panahi, P. (2015): Individual and annual variation in acorn production of Brant's oak (Quercus brantii Lindl.) in Darbadam Forest of Kermanshah province. - Iranian Journal of Forest and Poplar Research 19(2): 205-220. (In Persian with English summary) 
[29] Rose, A. K., Greenberg, C. H., Fearer, T. M. (2012): Acorn production prediction models for five common oak species of the eastern United States. - The Journal of Wildlife Management 76(4): 750-758.

[30] Sabeti, H. (2016): Forests, Trees and Shrubs of Iran. - Yazd University, Yazd. (In Persian)

[31] Sagheb Talebi, Kh., Sajedi, T., Pourhashemi, M. (2014): Forests of Iran: A Treasure from the Past, a Hope for the Future. - Springer, Netherlands.

[32] Sakal, R. R., Rohlf, F. J. (2012): Biometry: The Principles and Practice of Statistics in Biological Research. - W.H. Freeman and Company, New York.

[33] Sork, V. L. (1993): Evolutionary ecology of mast-seeding in temperate and tropical oaks (Quercus spp.). - Vegetatio 107/108: 133-147.

[34] Sork, V. L., Bramble, J., Sexton, O. (1993): Ecology of mast-fruiting in three species of North American deciduous oaks. - Ecology 74(2): 528-541.

[35] Steen, C., Jensen, R., Vangilder, L., Sheriff, S. (2009): Hardmast production in the Missouri Ozarks: a preliminary report of acorn production on MOFEP. - Resource Science Division, Missouri Department of Conservation, Missouri. 